\title{
AN EXPLORATORY STUDY ON THE ECOTOURISM SMALL BUSINESS IN MUKIM PANTAI, SEREMBAN, NEGERI SEMBILAN
}

\author{
Rohaizah Abd Latif, Rafidah Aris and Muhamad Naim Kamari \\ Unitar International University, Malaysia
}

\begin{abstract}
Ecotourism is a form of tourism involving visiting fragile, pristine, and relatively undisturbed natural areas, intended as a low-impact and often small scale alternative to standard commercial mass tourism. It means responsible travel to natural areas conserving the environment and improving the well-being of the local people. The purpose of the study is to explore the effects of emerging ecotourism small business through elements or variables such as social-culture effects, economic effects and environment effects. Qualitative method was used in this research by using semistructured interviews. The result of this research has shown that the above-mentioned elements have significantly influenced the future sustainable tourism development of such tourism product in the study area.
\end{abstract}

Key words: Ecotourism, Small Business, Social-Culture Effects, Economic Effects, Environment Effects, Local Community.

Cite this Article: Rohaizah Abd Latif, Rafidah Aris and Muhamad Naim Kamari, An Exploratory Study on the Ecotourism Small Business in Mukim Pantai, Seremban, Negeri Sembilan, International Journal of Management, 11(12), 2020, pp 395-403. http://iaeme.com/Home/issue/IJM?Volume=11\&Issue=12

\section{INTRODUCTION}

Ecotourism is a sub-sector in the tourism industry and has a meaningful linking with other sustainable tourism products. This type of sub-sector is related to the village or rural areas, hinterland and countryside as it involved by providing occupation opportunity as well as earnings to the local community, apart of providing unique holiday experience to vacation seeker or traveller that into ecology oriented. Moreover, ecotourism are mostly gratified to the accommodation service, attractions environment and local socioeconomic. According to the latest International Ecotourism Society website (2018), the definition of Ecotourism itself is related to sustainable matter whereby travelling with responsible attitude or demeanour towards natural environment (conservation towards environment), sustains the well-being of the local community and comprises of education and elucidation (towards staff and guest/visitor). This article brings Mukim Pantai, Seremban, Negeri Sembilan as a study area 
of investigating the towards the elememts. Mukim Pantai or sub-district of Pantai is on the west coast of peninsular Malaysia and it's delimited at the northern part of Selangor and eastern Pahang. This sub-district is comprised of 3 Jawatankuasa Keselamatan \& Kemajuan Kampung (JKKK) or the Village's Safety and Development Committee, consist of JKKK Batu 7, JKKK Batu 8 and JKKK Batu 9.

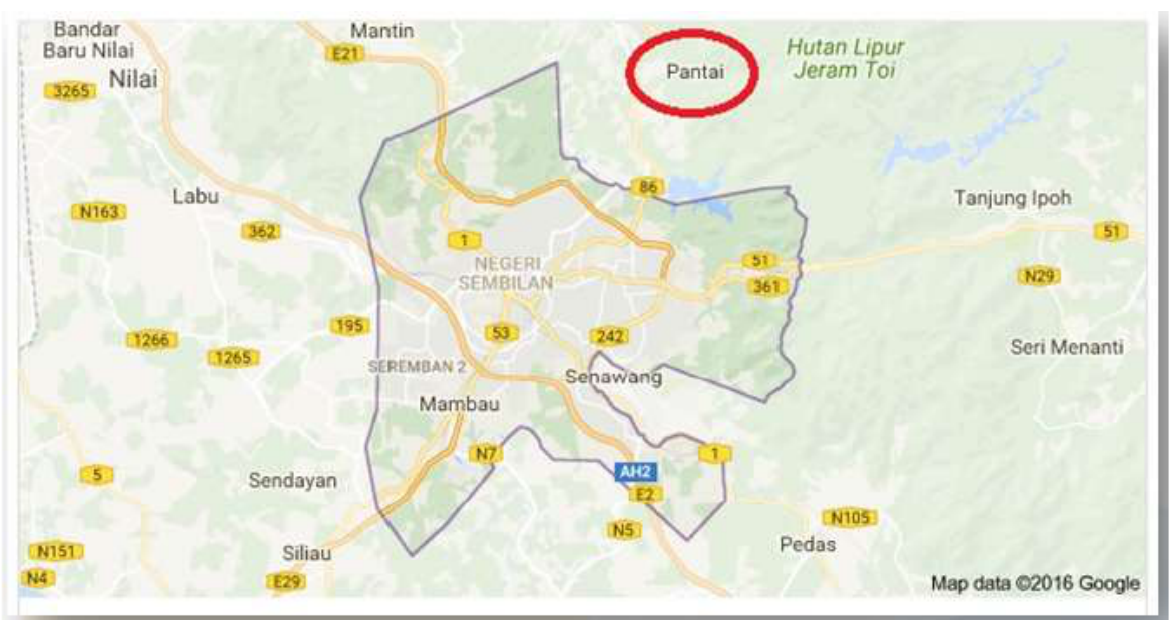

Figure 1 Map of Seremban (Source: Google Map, 2018)

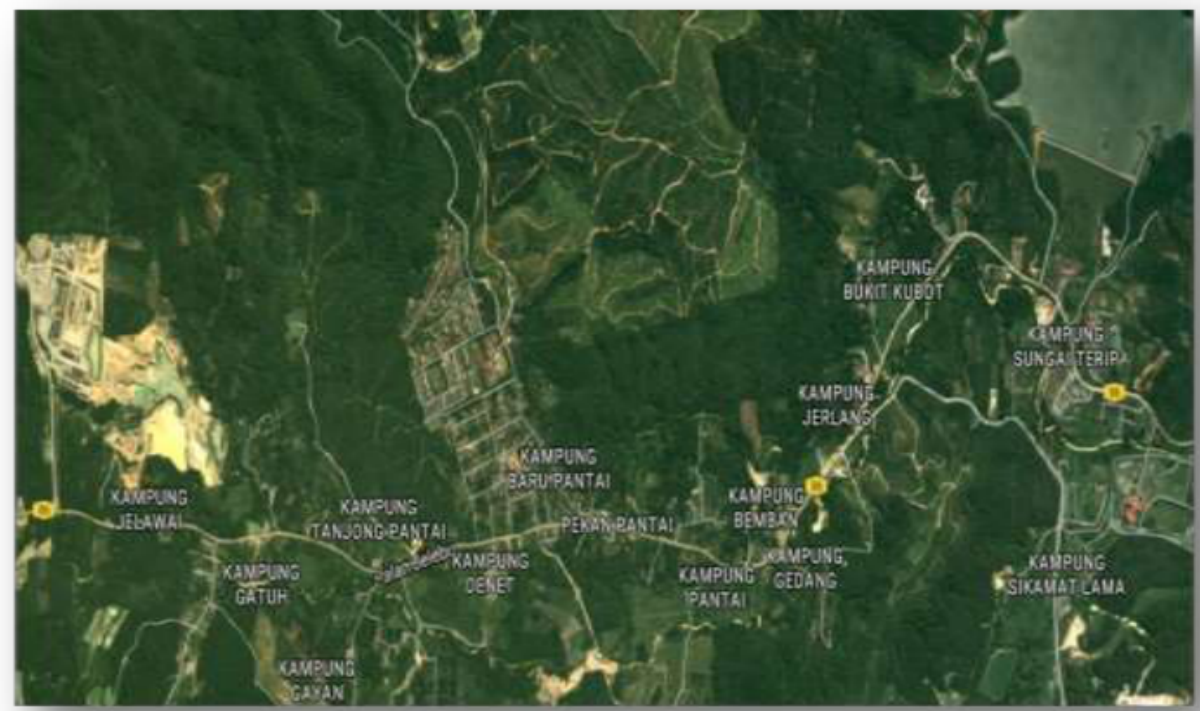

Figure 2 Map of Mukim Pantai (Source: Google Map, 2018)

\section{RESEARCH ISSUE}

As published in the article written by eturbonews.com (2018), Malaysia is well-known as a topmost tourism destination. The reason being, Malaysia has the best breath taking landscapes, vivacious cities, appealing history, social-culture, art heritage, nice food, and few of the most stunning beaches in the world. The Malaysian government has continuously promoting and emerging ecotourism as defined in the National Ecotourism Plan, since the Ninth Malaysia Plan period 2006-2010. This plan is mainly focus to guarantee equal development and sustainable development which is benefited in term of local community 
social-culture, economic and environment, without grudging the host location or destination natural-culture resources. Nevertheless, as per reported by Corinne Wan via Travel Weekly Asia webpage (2016) pertaining towards previous 2017 national budget presented by Malaysian Prime Minister - Datuk Seri Najib Tun Razak, cited that Malaysia's tourism industry has received a handsome amount of RM400 million (US\$96m) in fresh funding under the 2017 national budget in order to fully promote, stimulate and boost the country tourism facilities in the country and he also added that the allocation was for 'clean air' and ecotourism initiatives.

\section{AIM OF STUDY}

The study is an investigation research toward the existing emerging small business ecotourism within the study area and what are the effects to the entire area especially to the local community. In addition, the study will lead to understanding both positive and negative effects towards the area as well as the local community. To reiterate, ecotourism development will have a positive impact on socio-economic activities of local communities with the involvement in ecotourism businesses (Er \& Nurul, 2013; Ceballos-Lascurain, 1996; Butler, 1980) .In tourism industry, mainly ecotourism, is believed to be quite sustainable source of income to the aborigines and village or rural people as it has the fruitfulness of natural and cultural resources especially in the developing countries (Briedenhann and Wickens, 2004; Chambers, 2000; Ponting, 2001; Schilcher, 2007).

\section{LITERATURE REVIEW}

\subsection{Ecotourism}

Ecotourism is a continuous tourism activity in conserving as well provides a tourist attraction that is conceptualized to the natural environment or artificial ecology (Er \& Nurul, 2013). Ecotourism component characterized by development sustainable will provide the indoor leisure facilities without destroying or threatening existing natural ecological environment. Ecotourism businesses will lead to increased employment and business opportunities to local communities as well as upgrading of infrastructure facilities in the success of the space to the tourist spaces. In addition, ecotourism development will have a positive impact to other aspects of community development, among others, health, education, basic amenities, satisfaction, emotion, culture and infrastructure of the space imagery (Kim, Uysal \& Sirgy, 2013). This is because ecotourism development will create a flow of money into space tourism that leads to developmental aspects to local communities.

\subsection{Social-Economy}

Ecotourism that into community-based oriented is publicized as a potential solution that can benefits towards the ecosystems as well as local people via giving the empowerment to the community. In almost other studies (ecotourism) are prudently not to deem such tourism product as the ultimate solution, but to recognize other surplus elements such as internal and external partnership, secure admission to venues and effective leadership that linked to a successful ecotourism business (Scheyvens, 1999; Goodwin, 2002; Vincent \& Thompson, 2002; Yaman \& Mohd, 2004; Zografos \& Oglethorpe, 2004; Charnley, 2005; Fuller, Buultjens \& Cummings, 2005; Kontogeorgopoulos, 2005; Stone \& Wall, 2005; Cusack \& Dixon, 2006; Lai \& Nepal, 2006; Morais et al, 2006). On the other hand, from an economic standpoint, many scholars has determined that such tourism shall produces and enhance the numerous-vast economic benefits such as foreign-exchange influxes (Mathieson and Wall, 1982), job opportunities (Keogh, 1990; Martin, 1995; Mason and Cheyne, 2000; Pearce, 1989), upsurge in personal salary or income (Keogh, 1990; Martin, 1995), enriched 
economic structure, and higher level standard of living as well as medium-higher income earner (Allen et al., 1988; Gilbert and Clark, 1997; Haralambopoulos and Pizam, 1996; Huang, 1993; Teye et al., 2002). In addition, ecotourism shall as well generate quite largely income to local economy, especially when it into local participation, such as working or become consultant to the host product or involve in the operation side (Wunder, 2000; Lindberg et al., 1996).

\subsection{Environmental}

The value towards the environment is related to several of benefit and purposes in term of ecological well-being and social-economy well-being (improving local community quality of life) (Rawat et al., 2008). However, giving a full-utmost attention towards the decline of recreation resources due to overuse by the human activity, this issue must be taking care especially during the forest or natural environment assessment (Zhang \& Zhou, 2013). For example, poor planning as well as management by the host product is one of the conflicts that contribute to the deprivation of the natural environment and harm to the natural surroundings Arni \& Khairil, 2013). Moreover, apart the above, in order to improve the quality of forest and its component, maintain the harmony, conjoining as well as incorporation in between the nature elements of flora and fauna, water, local communities and environment, host product should have good development planning and systematic management practice (Wahida Ayob ,2006). As per Cunha (2010) however, claims that the deprivation of the natural environment shall become worse due to the malpractice of tourism activity. Hence, it (surrounding environment and natural resources) need to handle with care by all parties, in order to guarantee the steadiness and conservation towards the natural environment.

\section{RESEARCH METHODOLOGY}

Qualitative method, entailed face to face or individual interview to encourage participants to give their feedback and responses. The procedure includes developing the semistructured/open-ended questions by guaranteeing the discussion topic is sustainably relevant, time management and selection of participants as well as observation. Manual descriptive analysis has been used to analyse the data collection. Sampling are taken from the people who are the local community reside in 'Mukim' Pantai area.

\section{FINDINGS}

\subsection{Social-Culture Effect}

The local involvement toward the ecotourism business can be divided into two main reason; voluntary and work or earning money. However, some of the participant is a not really get involve directly with the said businesses as it mainly participate only through their community club or society programs. Additionally, the relationship between the businesses and local community are considered to be in normal-harmony environment. So far, there is no huge issue or problems since the emerging of such businesses within the study area. Moreover, participants have mixed view when commenting about the suitability of the said businesses in Mukim Pantai. From the observation, Mukim Pantai has quite ample and attractive natural resources and greenery setting. When asking about the benefit toward the community, it can be describe as a positive vibe toward the community well-being. Additionally, it also helps in term of enhancing knowledge or learning new knowledge or skill. In the relation to the positive and negative effect, participant somehow claimed that the positivity are more significant than negativity. Finally, the discussion lead to the conversation toward the changes or interference of local community lifestyle, daily life or norm, since the emerging of ecotourism businesses. Some of the participant claimed that their daily life or 
lifestyle has never change or interrupted by the businesses and few saying that it somehow 'disturb' by the businesses in term of overcapacity or non-control of visitor by some of the private villa.

\section{Table 1}

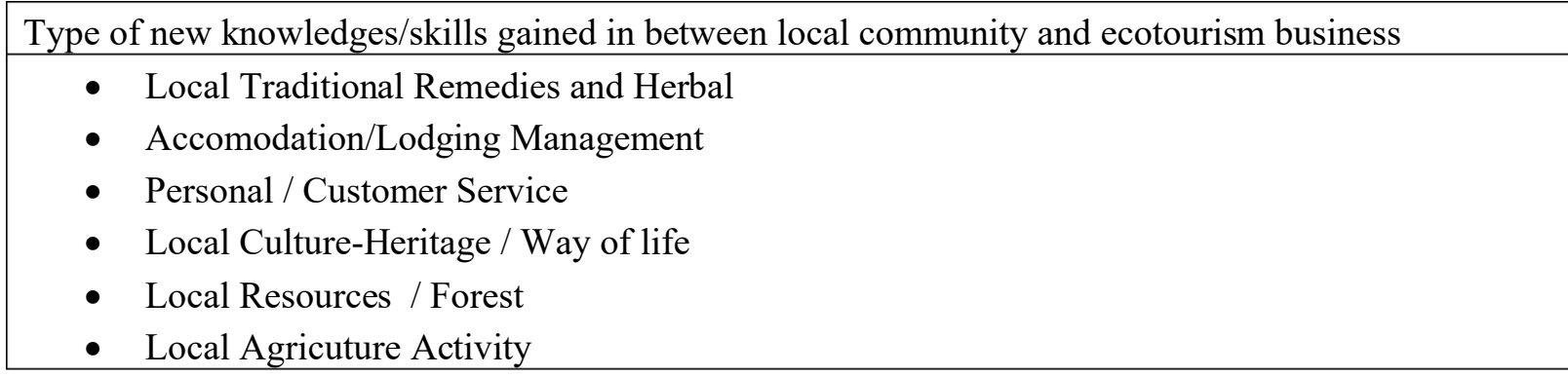

\subsection{Economic Effect}

Most of the participants are consider that the ecotourism business within the area are reasonably open the economics opportunity to the local community, even though in small scale. In addition, the agriculture is the most economy activity in Mukim Pantai, way before the emerging of ecotourism businesses. According to most of the participant, the effects are more towards economic value, whereby some of the farm owner co-work with the ecotourism businesses. Finally, the discussion is lead to the effects outside the study area which the neighboring areas. Most of the participant has agreed that there are no significant changes or effect, since the emerging of ecotourism business in Mukim Pantai.

Table 2

\begin{tabular}{|l}
\hline Type of Businesses BEFORE emerging of Ecotourism Business \\
- \\
- Agtty traders \\
- Small vegetable and fruites market \\
- Sasic convenient shop \\
\hline Type of new businesses AFTER emerging of Ecotourism business \\
\hline \\
- Catering service \\
- Cleaning service \\
- PA system service \\
- Traditional massage service (in-call) \\
- Private transportation service \\
- Restaurant (medium) \\
\hline
\end{tabular}

\subsection{Environment Effect}

The environment topic has been defined by most of the participant as important issue. This is because as a villager, surrounding environment is significantly interrelated with each other, as it a 'heritage property' that being passed from generations to generations. Moreover, most of the participant felt the benefit (environmentally) from the business activity. The benefit is 
more into cleanliness. Finally, the opinion towards the effect towards the environment and natural resources as a whole has different interpretation from the participant.

Table 3

Benefits (environmentally) towards the local community since the emerging of ecotourism business

- Well preserved river/stream/waterfall (leisure activity)

- Upgraded road system (easy access)

- Fresh and clean surrounding (less polluted quality of air)

- Well preserved forest (Mount Berembun-hiking activity)

\section{DISCUSSION}

The effects are showed through the local involvement, relationship between the businesses and local community, suitability of the businesses, local community social well-being, positive or negative effect and local community lifestyle. The local involvement is divided into two, which is voluntary and non-voluntary (work or earning money) at the ecotourism business premise. However, there is also indirectly involvement, whereby it through the commitment with the local community society or club (event or program that include participation from JKKK and ecotourism businesses). On the relationship between the local people and ecotourism businesses, can be deemed as normal-harmony environment. This is because there is no big or serious issue and as far as this research concern, all the ecotourism businesses is still maintain and understanding the local community rules and sensitivity.In addition, due to the greenery and preserved natural resources, such tourism product as ecotourism is definitely suitable to be emerging and explore in Mukim Pantai. This has being showed through the observation and feedback from most of the participant. However, there is also feedback suggest that, suitability (environment and local people) are not really important point when come to do business as it all rely on the capital (money), thus some investor or business owner will not really look into it. Moreover, in term of local community social wellbeing, ecotourism business has helps via creating sense of togetherness and closeness among the local people. This is through organizing joint-venture programs between both businesses and local people. Apart from that, the local people social well-being is also through promoting the ecotourism businesses value, such as knowledge sharing, adventure and learning new skills that provide by the ecotourism product and services. Thus, also has created some sense of educational. Tremendously, the positive effect is the greatest element since the emerging of ecotourism businesses. This is because it has not only benefited the local community, as it also in a way has created some sense of community branding toward the entire study area. Thus, this has more or less enhanced the local people social well-being.Nevertheless, the ecotourism businesses have never or little bit effect or interfere on the local people lifestyle. However, the only little issue is that some of the ecotourism business is 'eager' to selling their product (especially lodging business) and tend to look into slight disturbance, such as visitor over-capacity (uncontrolled). The effects are showed through the individual benefit in term of economic scale, economic opportunity between local community and ecotourism business, comparison between before and after such tourism product, effect toward the agriculture as the core economic activity and effect toward the neighbouring areas. In term of personal economic benefit, it has described through the simple life style which mean there is not much affected or change. However, it has more or less benefit through personal cost saving as some of the services or attractions (ecotourism business) are within short distance as no need to go far outside the area. Moreover, it also benefited in term of providing business or side income opportunity towards the local community who into money-making. In addition, economic opportunity or business opportunity, ecotourism businesses has also create sense of inspiration in a way it has stimulated the creative mind to some local people in setting up a 
business (sub-service or supplier) that relates to the ecotourism and it not necessary to have premises or centre. In relation to this, it also benefits the businesses in term of access of local resources apart well as business opportunity. The differential in between before and after such tourism product has quite small effect as there is not much change occurred. This is maybe, of because of the small scale businesses. However, to some local community, the arrival of reasonable amount of local and foreign visitor (especially during the weekend), has so far the most significant changes or differential since the emerging of the ecotourism business. Thus, has more or less enhanced the economic scale especially to the petty traders (owned by the local) around the area. Besides, the atmosphere surrounding the area has little bit change to more lively.In addition, since the agricultural are the largest economic activity in the area, some of the owner has benefited through co-working with the ecotourism businesses and thus has affected their economy as well as enhancing or broaden their business length. In the matter of the outside or neighbouring areas, the only issue is towards the traffic congestion along the main road, whereby Mukim Pantai is sharing the same main road with other neighbouring areas. Hence, it has quite affected the traffic flow especially during the weekend.

Finally, The topic about environment has been defined as important issue. This is because as a villager, surrounding environment is significantly interrelated with each other, as it some kind of 'heritage property' that being passed from generations to generations. As overall condition towards the surrounding environment which includes the natural resources, it deemed to at the ample or reasonable condition and there is no serious issue since the emerging of the ecotourism businesses. However, the only issue is towards the illegal sand mining which effected the river and it is not relates to the said businesses. Additionally, a concern is also towards the usage of the waterfall by the private villa's visitor, whereby some of the visitor will bath and using chemical shampoo and afraid it could more or less polluted the waterfall if it not being control. Though, positive effect are showed through the usage of the local resources by the ecotourism businesses, whereby it deemed to be the under control and minimal. This is because the businesses are on small scale. Moreover, the positive effect is also towards the good improvement of cleanliness at the most of the area in Mukim Pantai, especially near to the ecotourism business premises. Additionally, the cleanliness element is also towards around the waterfalls, village's road, and the surrounding the villages, whereby it transformed beautifully within the study area. The effort (cleanliness) is also given by the most of the ecotourism business as a part of their responsibility towards environment preservation. With their weekly routine in preserving the cleanliness of the river to creating eco-friendly waste trap system inside the river, are few of the effort as well as contribution given by the ecotourism businesses to the local community well-being as well as to the environment.

\section{REFERENCES}

[1] Allen, L.R., Long, P.T., Perdue, R.R. and Kieselbach, S. (1988), "The impact of tourism development on residents' perceptions of community life", Journal of Travel Research, Vol. 27 No. 1, pp. 16-21.

[2] Arni AG, Khairil WA (2013) Promoting collaboration between local community and park management towards sustainable outdoor recreation. Procedia - Social and Behavioral Sciences 91, 57-65.

[3] Briedenhann, J. and Wickens, E. (2004), "Tourism routes as a tool for the economic development of rural areas-vibrant hope or impossible dream?", Tourism Management, Vol. 25 No. 1, pp. 71-79. 
An Exploratory Study on the Ecotourism Small Business in Mukim Pantai, Seremban, Negeri

Sembilan

[4] Butler RW (1980) The concept of a tourist area cycle of evolution: Implication for management of resources. Canadian Geographer 24(1), 5-12.

[5] Ceballos-Lascurain H (1996) Tourism, ecotourism and protected areas. Gland, IUCN, Switzerland

[6] Chambers, E. (2000), Native Tours: The Anthropology of Travel and Tourism, Waveland Press,Prospect Heights, IL.

[7] Charnley, S. (2005). From nature tourism to ecotourism? The case of the Ngorongoro Conservation Area, Tanzania. Human Organization, 64, 75-88.

[8] Cusack \& Dixon (2006). Community-based ecotourism and sustainability: cases in Bocas del Toro Province, Panama and Talamanca, Costa Rica. Journal of Sustainable Forestry, 22, 157182.

[9] Cunha AA (2010) Negative effects of tourism in a Brazilian Atlantic Forest National Park. Journal for Nature Conservation 18, 291-295.

[10] Er Ah Choy, Nurul Bariah Mat Lazim (2013) Tahap kefahaman ekopelancongan dalam kalangan komuniti lokal di Lata Jarum, Raub, Pahang. Geografia-Malaysian Journal of Society and Space 8(2), 27-34.

[11] Fuller, D., Buultjens, J. \& Cummings, E. (2005). Ecotourism and indigenous microenterprise formation in northern Australia opportunities and constraints. Tourism Management, 26, 891904.

[12] Gilbert, D. and Clark, M. (1997), “An exploratory examination of urban tourism impact with reference to residents attitudes in the cities of Canterbury and Guildford", Cities, Vol. 14 No. 6, pp. 343-352.

[13] Goodwin, H. (2002). Local community involvement in tourism around National Parks: opportunities and constraints. Current Issues in Tourism, 5, 338-360.

[14] Haralambopoulos, N. and Pizam, A. (1996), "Perceived impacts of tourism: the case of Samos", Annals of Tourism Research, Vol. 23 No. 3, pp. 503-526.

[15] Huang, Y. (1993), "A context to understand the influence of tourism development on a rural community", unpublished thesis, Texas A\&M University, College Station, TX.

[16] Keogh, B. (1990), "Public participation in community tourism planning", Annals of Tourism Research, Vol. 17 No. 3, pp. 449-465.

[17] Kim K, Uysal M, Sirgy MJ (2013) How does tourism in a community impact the quality of life of community residents? Tourism Management 36, 527-540.

[18] Kontogeorgopoulos, N. (2005). Community-based ecotourism in Phuket and Ao Phangnga, Thailand: partial victories and bittersweet remedies. Journal of Sustainable Tourism, 13, 4-23.

[19] Lai, P. \& Nepal, S. (2006). Local perspectives of ecotourism development in Tawushan Nature Reserve, Taiwan. Tourism Management, 27, 1117-1129.

[20] Lindberg, K., Enriquez, J. and Sproule, K. (1996), "Ecotourism questioned: case studies from Belize", Annuals of Tourism Research, Vol. 23 No. 3, pp. 543-562

[21] Malaysia, 2006. The Ninth Malaysia Plan, Kuala Lumpur. Economic Planning Unit

[22] Martin, S.R. (1995), "Montanans' attitudes and behavioral intentions toward tourism: implications for sustainability", in McCool, S.F. and Watson, A.E. (Eds), Linking Tourism, the Environment, and Sustainability - Topical Volume of Compiled Papers from a Special Session of the Annual Meeting of the National Recreation and Park Association, p. 69-76, Intermountain Research Station, Ogden, UT

[23] Mason, P. and Cheyne, J. (2000), "Residents' attitudes to proposed tourism development", Annals of Tourism Research, Vol. 27 No. 2, pp. 391-441. 
[24] Mathieson, A. and Wall, G. (1982), Tourism: Economic, Physical and Social Impacts, Longman, London, New York, NY

[25] Morais, D., Zhu C., Dong E., \& Yang G. (2006). Promoting sustainability through increased community involvement: the Shangri-La Ecotourism Demonstration Project. Tourism Review International, 10, 131-140.

[26] Pearce, D. (1989), Tourism Development, 2nd ed., Longman, New York, NY

[27] Ponting, J. (2001), "Managing the Mentawais: an examination of sustainable tourism management and the surfing tourism industry in the Mentawai Archipelago, Indonesia", Master's thesis, University of Technology, Sydney.

[28] Rawat TS, Menaria BL, Dugaya D, Kotwa PC (2008) Sustainable forest management in India. Current Science 94 (8), 25 April 2008

[29] Scheyvens, R. (1999). Ecotourism and the empowerment of local communities. Tourism Management, 20, 245-249.

[30] Schilcher, D. (2007), "Growth versus equity: the continuum of pro-poor tourism and neoliberal governance", Current Issues in Tourism, Vol. 10 Nos 2-3, pp. 166-193.

[31] Stone, M. \& Wall, G. (2005). Ecotourism and community development: the case of Jianfengling National Forest Park, Hainan, China. China Tourism Research, 1, 78-100

[32] Teye, V., Sirakaya, E. and Sonmeza, S.F. (2002), "Residents' attitudes toward tourism development", Annals of Tourism Research, Vol. 29 No. 3, pp. 668-688.

[33] The international ecotourism society www.ecotourism.org/news/ties-announces-ecotourismprinciples-revision 'TIES Announces Ecotourism Principles Revision'

[34] Vincent, V. \& Thompson, W. (2002). Assessing community support and sustainability for ecotourism development. Journal of Travel Research, 41, 153-160.

[35] Wahida Ayob (2006) Pengurusan hutan rekreasi Sungai Tekala, Hulu Langat, Selangor: Analisis kajian pada hujung minggu. In: Hamidi Ismail, Tuan Pah Rokiah Syed Hussain, Johan Afendi Ibrahim (eds) Pengurusan Persekitaran dan Pelancongan di Malaysia: Konsepsi dan Kajian, pp.147-173. Universiti Utara Malaysia, Sintok.

[36] Wunder, S. (2000), "Ecotourism and economic incentives - an empirical approach", Ecological Economics, Vol. 32 No. 3, pp. 465-479.

[37] Yaman, A. \& Mohd, A. (2004). Community-based ecotourism: a new proposition for sustainable development and environmental conservation in Malaysia. Journal of Applied Science, 4, 583-589

[38] Zhang Y, Zhou X (2013). A study of forest recreation evaluation model in China. Procedia Computer Science 24, 280-288.

[39] Zografos, C. \& Oglethorpe, D. (2004). Multi-criteria analysis in ecotourism: using goal programming to explore sustainable solutions. Current Issues in Tourism, 7, 20-43. 